Якубенко Богдан Олександрович аспірант кафедри публічного управління та адміністрування Інституту підготовки кадрів державної служби зайнятості України, вул. Нововокзальна, 17, м. Київ, 03038, тел.: (044) 536-14-85, https://orcid.org/0000-0002-2813-9157

\title{
ДЕРЖАВНА ПОЛІТИКА НА РИНКУ ПРАЦІ ПІД ЧАС ПАНДЕМІЇ В УМОВАХ ГЛОБАЛІЗАЦІї
}

Анотація. У статті розглянуто державну політику на ринку праці під час пандемії. Проаналізовано державну політику скорочення державних соціальних видатків з метою зменшення дефіциту державного бюджету, національних боргів та зниження податку на прибуток, їх вплив на національну економіку. Визначено, що гонитва за неолібералізмом та дерегуляцією ринків праці зробила суспільства більш вразливими до наслідків пандемії. Підкреслено, що пандемія COVID-19 стала викликом для системи глобального управління охороною здоров'я, що $є$ одним із наслідків масової приватизації послуг охорони здоров'я. Кінцевим результатом цього стала нездатність системи охорони здоров'я подолати сучасні пандемічні виклики. Зазначено, що економічні системи, що сприяють нерівності, несумісні з ефективною охороною здоров'я та добробутом населення.

Звертається увага на те, що економічна складова кризи COVID-19 зумовлена закриттям галузей та закриттям імпорту проміжних продуктів із негативними наслідками для експортерів. У той же час події, спричинені глобальною пандемією COVID-19, також викривають безвідповідальність деяких урядів, дозволяючи занепад цілих промислових секторів, особливо в машинобудуванні та тяжкій промисловості. Зазначається, що повернення до концепції стратегічних секторів $є$ життєво важливим для того, щоб політика відновлення національної економіки стала ефективною в довгостроковій перспективі.

Акцентується увага на тому, що пандемічна криза виявила глибокі розбіжності в Європі, зокрема між умовно Північною та Південною Європою. При цьому в політиці, яку здійснюють країни Свропи, проявляється відсутність співфінансування державних видатків, задіяних у боротьбі 3 пандемією та подальшими програмами відновлення. Обгрунтовується припущення, що довгострокові наслідки такого протистояння, можуть призвести до подальшого політичного поділу всередині ЄС.

Ключові слова: державна політика, охорона здоров'я, ринок праці, пандемія, COVID-19. 
Yakubenko Bohdan Oleksandrovych Postgraduate student of Public Administration Department of Institute of Personal Training of the State Employment Service of Ukraine, Novovokzalna St., 17, Kyiv, 03038, tel.: (044) 536-14-85, https://orcid.org/0000-0002-2813-9157

\section{PUBLIC POLICY OF A LABOUR MARKET DURING THE PANDEMIC PERIOD IN CONTEXT OF GLOBALIZATION}

Abstract. The article presents the public policy of a labor market during the pandemic period. The analysis of the public policy reduction of state social expenditures in order to reduce the state budget deficit and national debts and reduce income tax, the impact on the national economy was carried out. It was determined that deregulation of labor markets has made society more vulnerable to the effects of a pandemic. Accordingly, it was emphasized that the COVID-19 pandemic was a challenge to the global health management system, which led to the mass privatization of health services. The end result has been the inability of the health care system to meet today's pandemic challenges. It was also observed that economic systems that promote inequality are incompatible with effective health and well-being.

It is emphasized that the economic component of the COVID-19 crisis is due to the closure of industries and the closure of imports of intermediate products with negative consequences for exporters. At the same time, the events caused by the global COVID19 pandemic also expose the irresponsibility of some governments, allowing the decline of entire industrial sectors, especially in mechanical engineering and heavy industry. It is noted that a return to the concept of strategic sectors is vital for a policy of national economic recovery to be effective in the long term.

The article rightly focuses attention on the fact that the pandemic crisis has revealed deep differences in Europe, in particular between the relatively northern and southern Europe. At the same time, the policy pursued by European countries shows a lack of co-financing of public expenditures involved in the fight against the pandemic and subsequent recovery programs. It is argued that the long-term consequences of such a confrontation could lead to further political divisions within the EU.

Keywords: public policy, health care, labor market, pandemic, Covid-19.

Постановка проблеми. Пандемія коронавірусу COVID-19 стала каталізатором нагальної потреби відновлення економічного, виробничого зв'язку, охорони здоров'я та інших секторів державної політики, які сучасні уряди зазвичай реформують шляхом їхнього дерегулювання. Також зростає соціальноекономічна нерівність, що деякі дослідники також пов'язують 3 політикою неолібералізму, яку світова спільнота, а також такі організації, як МВФ та 
Світовий банк, впроваджують в обмін на їх допомогу та кредити. Така державна політика створює привілейовані ринки праці, збільшує корпоративне багатство та капітал окремих акторів, однак послаблює довгострокові національні інтереси суспільств які погоджуються на таку допомогу. Така політика, в свою чергу, спричиняє падіння частки доходів громадян від праці, у тому числі, за рахунок збільшення виплат зарплат керівництву (на кшталт багатосоттисячних заробітних плат членам наглядових рад на фоні банкрутуючих підприємств Укрзалізниці, Укроборонпрому та інших), що сприяє безпрецедентному зростанню нерівності та популістській реакції на такі дії в суспільстві.

Аналіз останніх досліджень і публікацій. Проблемні питання політики на ринку праці під час пандемії за останні роки було масово розглянуто закордонними дослідниками та науковцями. Дослідження динаміки ринків під час пандемії аналізувались у працях А. Аткінсона, Б.Крейна, Д. Лазоніка, П. Хетча. Фундаментальними для нашого дослідження є роботи знаних дослідників Л. Гаррета, П. Левін, Е.Геббі, А.Поллока.

Мета статті: визначити тенденції урядових політик на ринку праці під час пандемії в умовах глобалізації.

Виклад основного матеріалу. Сучасні уряди продовжувють скорочувати державні соціальні видатки з метою зменшення дефіциту державного бюджету та національних боргів [1, 2], а також посилюючи нерівність, особливо в сферах, що стосуються охорони здоров'я та освіти. Падіння частки праці в доходах та зростання нерівності також означають зменшення сукупного попиту та купівельної спроможності громадян, що можна було підтримати лише за рахунок залучення інвестицій - як внутрішніх, так і зовнішніх. За даними Світового банку, поточна „глобальна хвиля боргу є найбільшою, найшвидшою за останні 50 років ” [3].

Загалом зниження податку на прибуток підприємств у країнах Свропи, на кшталт зниження ставки ССВ в Україні, не стало поштовхом для інвестицій та економічного зростання. Прибуток, а також зниження податків та грошові кошти держави використовувались для виплати дивідендів та викупу облігацій внутрішньої державної позики (ОВДП), замість повторного інвестування для підвищення продуктивності, розширення виробничого потенціалу держави або створення запобіжних резервів для виходу 3 кризи. Така короткострокова корпоративна поведінка завищує ціни акцій, ОВДП, збільшуючи винагороду представників топ-менеджменту виконавчої влади, яку канадський економіст В. Лазонік назвав «прибутком без процвітання», а за словами дослідника зі США Дж. Крейна, виявляє «суперечності» капіталізму акціонерів [4, 5].

Продаж державних активів - ключовий стовп неолібералізму - мав лише тимчасовий або короткочасний вплив на державний борг, але погіршив довгострокову спроможність урядів залучати доходи через втрату прибуткових 
активів приватизованих підприємств. Нові приватні власники використовували нормативні лазівки, щоб уникнути сплати податків або ухилитися від них. Наприклад, в Австралії приватизація таких основних природних монополій, як порти та інфраструктура електроенергетики, створила монополії або олігополії, посилюючи нерівність, тоді як маркетизація професійно-технічної освіти підірвала довіру як громадськості, так і колишніх прихильників дерегуляції [6].

Таким чином, гонитва за неолібералізмом та дерегуляцією ринків праці зробила суспільства більш вразливими до наслідків пандемії (включаючи зменшену та приватизовану інфраструктуру охорони здоров'я). Менші пандеміі (Ебола та особливо ГРВI) були попереджувальними сигналами. Нинішня пандемія не являла собою приклад непередбачуваної загрози для безперервно функціонуючої та стійкої економічної системи. Це кинуло виклик режиму, який досі намагається вийти з глобальної фінансової кризи. COVID-19 демонструє, що суспільства повинні розставити пріоритети в ряді соціальних цілей, включаючи охорону здоров'я та добробуту населення. Якщо вони хочуть захистити своїх громадян, уряди повинні визнати, що економічні системи, що сприяють нерівності, несумісні з ефективною охороною здоров'я та добробутом населення. Пандемія посилює розбіжності, коли, наприклад високооплачувані спеціалісти 3 інформаційних технологій, що здатні працювати вдома, отримують незмінний дохід, а мільйони ключових працівників у низькооплачуваних секторах роздрібної торгівлі та послуг залишаються без роботи та оплати праці повністю або частково. Доля корпорацій, пов'язаних із цифровими гігантами та великими фармацевтичними компаніями, зростає багаторазово, а виробничий сектор зазнає стагнації.

Науковці загалом попереджають про глобальну пандемію протягом десятиліть [7, 8]. Деякі стверджують, що державні системи охорони здоров'я, що фінансуються та управляються державою, $\epsilon$ найбільш ефективними та результативними [9]. Наприклад, слабкі сторони американської приватної системи платних послуг у системі охорони здоров'я показали ї нездатність боротьби з пандемією. У Сполученому Королівстві Національна служба охорони здоров’я (NHS) зазнавала багаторічної економії, включаючи скорочення витрат, реструктуризацію, квазіприватизацію, аутсорсинг та казуалізацію робочої сили [10]. Світовий банк протягом трьох десятиліть рекомендував моделі приватизації сектору охорони здоров'я для країн із низьким та середнім рівнем доходу, надаючи позики після обов’язкового виконання таких рекомендацій [11].

Кінцевим результатом вищезазначених кроків стала нездатність системи охорони здоров'я подолати сучасні пандемічні виклики, такі як забезпечення населення засобами індивідуального захисту. Нерівномірне послаблення системи охорони здоров'я не змогло ефективно відреагувати та ефективно керувати 
загальнонаціональними системами охорони здоров'я, на відміну від системи Семашко, яка є більш ефективною за звичайних обставин, а тим більше під час пандемії, хоча й потребує значних фінансових витрат

Так, нестача засобів індивідуального захисту виникла у всьому світі. Відсутність запасів для використання в умовах пандемії постала внаслідок підходів до медичних закупівель за системою «точно і вчасно», що заощаджують кошти, однак вимагають серйозного стратегічного планування. Пандемія висвітлила обмеження контрольованих корпораціями глобалізованих вертикальних ланцюгів медичних поставок. Навіть країнам 3 високим рівнем доходу було важко забезпечити життєво важливе обладнання (маски, захисний одяг та апарати ШВЛ), оскільки воно сильно залежало від імпорту. Відсутність засобів індивідуального захисту створювала численні ризики для медичних працівників, особливо враховуючи інфекційний характер COVID-19. Міжнародна рада медичних сестер [12] підрахувала, що в Італії, одній з високо розвинутій європейській країні, яка найбільше постраждала від пандемії, 9\% смертей спричинили медичні працівники через брак засобів індивідуального захисту. Зображення медичних працівників, які протестують через відсутність доступних засобів індивідуального захисту, підкреслюють високий рівень смертності серед медперсоналу. Британська газета «Гардіан» зафіксувала смерть кожного медичного працівника в колонці з некрологами [12].

Пандемія COVID-19 стала викликом для системи глобального управління охороною здоров'я, що склалася після Другої світової війни, структурованій навколо установ ООН. Хоча реакція Всесвітньої організації охорони здоров’я (BOO3) на пандемію, безумовно, не була досконалою, ця організація забезпечила глобальне лідерство, надаючи засоби індивідуального захисту країнам з низьким та середнім рівнем доходу, збираючи та аналізуючи інформацію щодо поширення хвороби, ефективності лікування, нових протоколів лікування, пошук вакцини тощо, незважаючи на хронічне недофінансування, що ускладняється відкликанням фінансової підтримки з боку адміністрації США Трампа. Бюджет ВОО3 на 2020-2021 роки становить близько 4,84 мільярда доларів, що наближається до річного бюджету великої лікарні США та приблизно на 2 мільярди доларів менше річного бюджету Центру контролю за хворобами США. Впливові розвинені країни, на жаль, заперечують, що вони послаблювали багатосторонні інституції, зокрема ВООЗ. Але між 1970-1971 та 2017 рр. вони зменшили свою частку надійного довгострокового фінансування ВОО3 з 62\% до 18\% ii бюджету [13], що суттєво обмежило можливості ВООЗ.

Вплив пандемії та реакція на неї різні групи населення відчувають не однаково. Соціальна ізоляція простіша для людей $з$ просторими будинками та надійним швидким Інтернетом. Люди, які живуть у перенаселених будинках 3 
малою чи небезпечною відкритою територією, відсутністю проточної води для миття рук та недостатнім доступом до Інтернету [14] будуть вразливішими до негативних наслідків ізоляції. Ті, хто займається незахищеною та випадковою роботою, першими звільняються і стикаються з безробіттям. Хоча уряди багатьох багатих країн забезпечували виплати на соціальне страхування або гарантували заробітну плату, у країнах 3 низьким та середнім рівнем доходів таких можливостей було небагато. Загалом пандемія майже напевно збільшить нерівність у системі національного здоров’ї як між країнами, так і всередині них. Також пандемія виявила неоднозначні наслідки для навколишнього середовища. Падіння туризму та подорожей (авіація та судноплавство) суттєво зменшило споживання нафти та забруднення, тоді як робота на дому сприяє зменшенню транспортних потреб. Якість повітря в деяких найбільш забруднених місцях світу радикально покращилася [15], викиди парникових газів різко впали [16], а міста від Венеції до Тель-Авіва стали свідками того, що дика природа «відновлює» міський простір. Деякі можливості для структурних змін у виробничих галузях відкрила власне пандемія. Такі держави, як Австралія, які покладаються на довгі транснаціональні ланцюги поставок та технології для стратегічних товарів та послуг, розглядають ризик таких моделей, диверсифікуючи джерела їх імпорту та рухаючись до збільшення внутрішнього виробництва [17]. Така парадигма коротких ланцюгів поставок може переконфігурувати сектор морських перевезень з високим рівнем викидів, відомий своєю шкідливою залежністю від мазуту, а також систематичним уникненням законодавства про працю та оподаткування [18]. Глобальний туризм, який в даний час відповідає за близько 8\% глобальних викидів, подібним чином може бути відновлений на більш нижчій, а отже, потенційно більш екологічно стійкій основі [19].

Однак моделі багатьох екологічно руйнівних галузей промисловості навряд чи можуть бути суттєво змінені коронавірусною кризою як такою. Промислове сільське господарство, на яке припадає 9\% парникових газів, $є$ основною причиною вирубки лісів, втрати біорізноманіття та забруднення води, а також промислове рибальство не має ознак відхилення від своїх стандартних підходів. Багато країн назвали сільське господарство критично важливим, що дозволило підприємствам працювати в звичному режимі, а великі агропромислові підприємства пообіцяли продовжувати працювати, хоч і 3 більш жорсткими гігієнічними та санітарними заходами.

Більшість світових криз, включаючи Велику депресію 1930-х років, були спричинені відсутністю попиту, або через обвал фондового ринку чи відсутність довіри до державної політики. Економічна складова кризи COVID-19 зумовлена закриттям галузей та закриттям імпорту проміжних продуктів із негативними наслідками для експортера. Зазвичай кризи пов’язані з безробітною робочою 
силою та надлишком виробничих потужностей, що робить відносно легким відновлення економіки за рахунок збільшення попиту. Але зараз галузі неможливо легко відновити, поки не закінчиться криза, спричинена пандемією. Навіть тоді багатьом галузям не вистачить ресурсів та капіталу, більшість із яких потрібно імпортувати. Тому необхідно ретельне планування відновлення економіки після пандемії. Події COVID-19 також викривають безвідповідальність деяких урядів, дозволяючи занепад цілих промислових секторів, особливо в машинобудуванні та тяжкій промисловості. Повернення до концепції стратегічних секторів є життєво важливим для того, щоб політика відновлення національної економіки була ефективною в довгостроковій перспективі. Важливість побудови стратегічних секторів, які ринкові процеси просто не здатні здійснити самостійно, полягає в тому, що події типу пандемії COVID-19, швидше за все, будуть повторюватися в найближчі роки та десятиліття.

Висновки. Пандемічна криза виявила глибокі розбіжності в Свропі, зокрема між умовно Північною та Південною Європою. Перші розбіжності виникли, коли Італія, спустошена пандемією, потребувала допомоги, заклики про яку решта Свропи проігнорувала. Розбіжності поглибилися, коли економічно зруйнована Південна Європа (Італія, Іспанія) наполягала на додатковому випуску єврооблігацій для фінансування національної економіки, на що Північна Європа (Німеччина, Польща, Голандія, Австрія) наклала вето. Довгострокові наслідки такого протистояння, ймовірно, призведуть до подальшого політичного поділу всередині ЄС. Що важливо, зараз Франція також опиняється на південній стороні розриву через іiі внутрішній та зовнішній дефіцит та відсутність потенціалу росту у деіндустріалізованих та децентралізованих стратегічних секторах, що відповідають за випуск медичної продукції. Таким чином проявляється відсутність співфінансування державних видатків, задіяних у боротьбі 3 пандемією та подальшими програмами відновлення. Голландія, підтримана Німеччиною та Австрією, відмовились від стратегії співфінансування державних видатків для боротьби з пандемією. А оскільки це держави із сильним зовнішнім профіцитом - економічним, соціальним, то це загрожує політичним розривом у Європі що, в свою чергу, ставить під загрозу світову економіку. ЄС як союз без трансфертів, як це зафіксовано у всіх фіскальних договорах єврозони, прийнятих після кризи 2008 року, опинився неготовим як перед пандемією, так і перед тривалою економічною кризою.

\section{Лimepamypa:}

1. Atkinson, AB (2000) Increased income inequality in OECD countries and the redistributive impact of the Government Budget. UNU-WIDER working paper no 202, October. Available at: https://ora.ox.ac.uk/objects/uuid:ae39f737-d82a-4146-abfa-270568be9051/download_file? 

2020).

2. International Monetary Fund (IMF) (2017) Fiscal Monitor 2017: tackling inequality, October 2017. Available at: https://www.imf.org/en/Publications/FM/Issues/2017/10/05/fiscal-monitoroctober-2017 (accessed 25 April 2020).

3. World Bank (2019) Global wave of debt is largest, fastest in 50 years. Available at: https://www.worldbank.org/en/news/press-release/2019/12/19/debt-surge-in-emerging-anddeveloping-economies-is-largest-fastest-in-50-years (accessed 10 May 2020).

4. Krein, J (2018) Share buybacks and the contradictions of 'shareholder capitalism'. American Affairs, 13 December. Available at: https://americanaffairsjournal.org/2018/12/share-buybacks-andthe-contradictions-of-shareholder-capitalism/ (accessed 25 April 2020).

5. Lazonick, W (2014) Profits without prosperity. Harvard Business Review, September. Available at: https://hbr.org/2014/09/profits-without-prosperity (accessed 20 April 2020).

6. Hatch, P (2016) Privatisation has damaged the economy, says ACCC chief. Sydney Morning Herald, 26 July. Available at: https://www.smh.com.au/business/privatisation-has-damaged-theeconomy-says-accc-chief-20160726-gqe2c2.html (accessed 20 April 2020).

7. Garrett, L (1994) The Coming Plague: Newly Emerging Disease in a World Out of Balance. New York: Penguin Books.

8. Levin, PJ, Gebbie, EN, Quereshi, K (2007) Can the health-care system meet the challenge of pandemic flu? Planning, ethical, and workforce considerations. Public Health Reports 122(5): 573578.

9. Mooney, G (2012) The Health of Nations: Towards a New Political Economy. London: Zed Books.

10. Pollock, AM, Price, D (2013) From cradle to grave. In: Davis, J, Tallis, R (eds) NHS SOS: How the NHS was Betrayed - and How We Can Save It. London: Oneworld, pp. 174-203

11. Lister, J, Labonté, R (2009) Globalization and health system change. In: Labonté, Schrecker, T, Packer, C, et al. (eds) Globalization and Health: Pathways, Evidence and Policy. New York: Routledge, pp. 181-212.

12. International Council of Nurses (2020) High proportion of healthcare workers with COVID19 in Italy is a stark warning to the world: protecting nurses and their colleagues must be the number one priority. Available at: https://www.icn.ch/news/high-proportion-healthcare-workers-covid-19italy-stark-warning-world-protecting-nurses-and (accessed 21 April 2020).

13. Marsh, S (2020) Doctors, nurses, porters, volunteers: the UK health workers who have died from COVID-19. The Guardian, 16 April. Available at: https://www.theguardian.com/world/2020/apr/16/doctors-nurses-porters-volunteers-the-uk-healthworkers-who-have-died-from-COVID-19 (accessed 21 April 2020).

14. Mahbubani, K (2020) Can humanity make U-turns? The Straits Times, 9 April. Available at: https://www.straitstimes.com/opinion/can-humanity-make-u-turns (accessed 23 April 2020).

15. Jones, S, Egger, E-M, Santos, R (2020) Is Mozambique prepared for a lockdown during the COVID-19 pandemic? UNU-WIDER Blog. Available at: https://www.wider.unu.edu/publication/ mozambique-prepared-lockdown-during-covid-19-pandemic (accessed 18 April 2020)

16. Ellis-Petersen, H, Rebecca, R, Sam, C, et al. (2020) 'It's positively alpine!': disbelief in big cities as air pollution falls. The Guardian, 11 April. Available at: https://www.theguardian.com/environment/2020/apr/11/positively-alpine-disbelief-air-pollutionfalls-lockdown-coronavirus (accessed 21 April 2020). 
17. Henriques, M (2020) Will COVID-19 have a lasting impact on the environment? Available at: https://www.bbc.com/future/article/20200326-COVID-19-the-impact-of-coronavirus-on-theenvironment (accessed 21 April 2020).

18. Duke, M (2020) Coronavirus triggers Australian self-sufficiency push. Sydney Morning Herald, 12 April. Available at: https://www.smh.com.au/politics/federal/coronavirus-triggersaustralian-self-sufficiency-push-20200412-p54j5q.html (accessed 21 April 2020).

19. Ellsmoor, J (2019) Cruise ship pollution is causing serious health and environmental problems. Forbes. Available at: https://www.forbes.com/sites/jamesellsmoor/2019/04/26/cruise-shippollution-is-causing-serious-health-and-environmental-problems/ (accessed 21 April 2020).

20. Coghlan, A (2018) Tourism is four times worse for the climate than we thought. New Scientist, 7 May. Available at: https://www.newscientist.com/article/2168174-tourism-is-four-timesworse-for-the-climate-than-we-thought (accessed 21 April 2020).

\section{References:}

1. Atkinson, A.B. (2000). Increased income inequality in OECD countries and the redistributive impact of the Government Budget. UNU-WIDER working paper no 202, October. Available at: https://ora.ox.ac.uk/objects/uuid:ae39f737-d82a-4146-abfa-270568be9051/download file?file_format=pdf\&safe_filename=wp202.pdf\&type_of_work=Working+paper $($ accessed 25 April 2020) [in English].

2. International Monetary Fund (IMF) (2017). Fiscal Monitor 2017: tackling inequality, October 2017. Available at: https://www.imf.org/en/Publications/FM/Issues/2017/10/05/fiscalmonitor-october-2017 (accessed 25 April 2020) [in English].

3. World Bank (2019). Global wave of debt is largest, fastest in 50 years. Available at: https://www.worldbank.org/en/news/press-release/2019/12/19/debt-surge-in-emerging-anddeveloping-economies-is-largest-fastest-in-50-years (accessed 10 May 2020) [in English].

4. Krein, J. (2018). Share buybacks and the contradictions of 'shareholder capitalism'. American Affairs, 13 December. Available at: https://americanaffairsjournal.org/2018/12/sharebuybacks-and-the-contradictions-of-shareholder-capitalism/ (accessed 25 April 2020) [in English].

5. Lazonick, W. (2014). Profits without prosperity. Harvard Business Review, September. Available at: https://hbr.org/2014/09/profits-without-prosperity (accessed 20 April 2020) [in English].

6. Hatch, P. (2016). Privatisation has damaged the economy, says ACCC chief. Sydney Morning Herald, 26 July. Available at: https://www.smh.com.au/business/privatisation-has-damagedthe-economy-says-accc-chief-20160726-gqe2c2.html (accessed 20 April 2020) [in English].

7. Garrett, L. (1994). The Coming Plague: Newly Emerging Disease in a World Out of Balance. New York: Penguin Books [in English].

8. Levin, P.J., Gebbie, E.N., \& Quereshi, K. (2007). Can the health-care system meet the challenge of pandemic flu? Planning, ethical, and workforce considerations. Public Health Reports 122(5): 573-578 [in English].

9. Mooney, G. (2012). The Health of Nations: Towards a New Political Economy. London: Zed Books [in English].

10. Pollock, A.M., \& Price, D. (2013). From cradle to grave. In: Davis, J, Tallis, $R$ (eds) NHS SOS: How the NHS was Betrayed - and How We Can Save It. London: Oneworld, pp. 174-203 [in English].

11. Lister, J., \& Labonté, R. (2009). Globalization and health system change. In: Labonté, R, Schrecker, T, Packer, C, et al. (eds) Globalization and Health: Pathways, Evidence and Policy. New 
York: Routledge, pp. 181-212 [in English].

12. International Council of Nurses (2020). High proportion of healthcare workers with COVID-19 in Italy is a stark warning to the world: protecting nurses and their colleagues must be the number one priority. Available at: https://www.icn.ch/news/high-proportion-healthcare-workerscovid-19-italy-stark-warning-world-protecting-nurses-and (accessed 21 April 2020) [in English].

13. Marsh, S. (2020). Doctors, nurses, porters, volunteers: the UK health workers who have died from COVID-19. The Guardian, 16 April. Available at: https://www.theguardian.com/world/2020/apr/16/doctors-nurses-porters-volunteers-the-uk-healthworkers-who-have-died-from-COVID-19 (accessed 21 April 2020) [in English].

14. Mahbubani, K. (2020). Can humanity make U-turns? The Straits Times, 9 April. Available at: https://www.straitstimes.com/opinion/can-humanity-make-u-turns (accessed 23 April 2020) [in English].

15. Jones, S., Egger, E-M., \& Santos, R. (2020). Is Mozambique prepared for a lockdown during the COVID-19 pandemic? UNU-WIDER Blog. Available at: https://www.wider.unu.edu/publication/mozambique-prepared-lockdown-during-covid-19pandemic (accessed 18 April 2020) [in English].

16. Ellis-Petersen, H., \& Rebecca, R. (2020). 'It's positively alpine!': disbelief in big cities as air pollution falls. The Guardian, 11 April. Available at: https://www.theguardian.com/environment/2020/apr/11/positively-alpine-disbelief-air-pollutionfalls-lockdown-coronavirus (accessed 21 April 2020) [in English].

17. Henriques, M. (2020). Will COVID-19 have a lasting impact on the environment? Available at: https://www.bbc.com/future/article/20200326-COVID-19-the-impact-ofcoronavirus-on-the-environment (accessed 21 April 2020) [in English].

18. Duke, M. (2020). Coronavirus triggers Australian self-sufficiency push. Sydney Morning Herald, 12 April. Available at: https://www.smh.com.au/politics/federal/coronavirus-triggersaustralian-self-sufficiency-push-20200412-p54j5q.html (accessed 21 April 2020) [in English].

19. Ellsmoor, J. (2019). Cruise ship pollution is causing serious health and environmental problems. Forbes. Available at: https://www.forbes.com/sites/jamesellsmoor/2019/04/26/cruise-shippollution-is-causing-serious-health-and-environmental-problems/ (accessed 21 April 2020) [in English].

20. Coghlan, A. (2018). Tourism is four times worse for the climate than we thought. New Scientist, 7 May. Available at: https://www.newscientist.com/article/2168174-tourism-is-four-timesworse-for-the-climate-than-we-thought (accessed 21 April 2020) [in English]. 